\title{
Should PLCs Diversify into Related or Unrelated Industries? Evidence from Malaysia
}

\author{
Khawaja Khalid Mehmood \\ Doctoral Scholar, Universiti Utara Malaysia, and Lecturer, Institute of Management Sciences, \\ Bahauddin Zakariya University Multan, Pakistan \\ Email: khalidmehmood17@yahoo.co.uk
}

\section{Haim Hilman}

Associate Professor, College of Business, Universiti Utara Malaysia

Email: hilman@uum.edu.my

\section{Doi:10.5901/mjss.2015.v6n1s1p517}

\section{Abstract}

The primary issue in diversification strategy is concerning its type. A large body of research on the relative effect of related versus unrelated diversification still remains inconclusive. Scholars have been studying this topic through different research designs and in different contexts, although a greater part of the research was conducted in western economies. Importantly, certain scholars have asserted that powerful conclusions could be produced if product diversification is measured using powerful techniques and performance is assessed through combination of objective and subjective measures. This research builds up on that suggestion and revisits the subject using a sample of Malaysian PLCs as Malaysia has always been characterised by proliferation of diversified companies. This is also imperative keeping in view the challenges confronted by Malaysian economy in recent years and the significant repercussions of selecting type of diversification by Malaysian corporate sector. This study was conducted for multi-business PLCs listed on Main Market of Bursa Malaysia. T-tests based on 123 diversified PLCs revealed that related diversifiers outperformed unrelated diversifiers on Tobin's $q$ and price/book value. The study carries significant theoretical implications along with practical implications for Malaysian corporate sector and other PLCs facing similar business scenarios as in Malaysia.

Keywords: Related Diversification, Unrelated Diversification, Corporate Performance, Malaysian PLCs

\section{Introduction}

One of the crucial strategic decisions faced by today's strategists is regarding product diversification strategy (Marinelli, 2011). Product diversification symbolizes a company's strategic flexibility (Abdullah, 2009), determines range of organization's activities (Johnson, Scholes, \& Whittington, 2008), and could demand major changes in organization's structure for its execution (David, 2011). In western economies, diversification trend persisted during 1960's and 1970's, however several multi-business companies converted to single business companies during 1980's (David, 2011; Gupta, Gollakota, \& Srinivasan, 2007). Conceivably, researchers' attention into performance consequences of product diversification also provoked in the course of diversification trend during those decades. Amidst, one of the leading questions concerning product diversification has been whether companies that diversify into related industries perform better than companies that diversify into unrelated industries (Dubofsky \& Varadarajan, 1987; Mehmood \& Hilman, 2013; Palich, Cardinal, \& Miller, 2000).

History of research on product diversification strategies is about forty years old and a huge body of research aimed at comparing performance of related diversifiers against unrelated diversifiers (Marinelli, 2011; Mehmood \& Hilman, 2013). However, four decades of research in comparing related versus unrelated companies have produced inconsistent and inconclusive results (Asrarhaghighi, Rahman, Sambasivan, \& Mohamed, 2013; Marinelli, 2011). If on one hand, certain studies found related diversification performing better than unrelated diversification (Mishra \& Akbar, 2007; Rumelt, 1974, 1982), on the other hand, many researches revealed that conglomerates performed better compared to related diversifiers (Marinelli, 2011; Michel \& Shaked, 1984).

A deep analysis of studies comparing related versus unrelated diversifiers reveals that those studies were different from one another regarding their designs and contexts. A sizeable portion of these studies was heterogeneous indicating the use of different techniques for measuring diversification strategies as well as performance (Asrarhaghighi et al., 2013; Benito-Osorio, Guerras-Martin, \& Zuniga-Vicente, 2012). Moreover, unlike Asian economies, most of the research on 
diversification strategies is available either in American context or of United Kingdom (Afza, Slahudin, \& Nazir, 2008; Mehmood \& Hilman, 2013).

Though use of variety in research methodologies provided greater insight into the topic but it created ambiguity as well (Christensen \& Montgomery, 1981; Palich et al., 2000). Importantly, certain scholars suggested that reliance on better methodologies for measuring product diversification and securing performance through multiple ways could provide better understanding about this area (Asrarhaghighi et al., 2013; Jusoh \& Parnell, 2008). Based on this argument, this research measured performance through objective and subjective approaches. Also, product diversification was measured using Jacquemin and Berry's (1979) powerful Entropy's measure.

Numerous scholars added that research into product diversification in context of Asia has mainly been inconclusive (Chakrabarti, Singh, \& Mahmood, 2007; Daud, Salamudin, \& Ahmad, 2009; Ishak \& Napier, 2006; Lins \& Servaes, 2002) and literature also reveals no harmony among research findings comparing related versus unrelated companies in the Asian context. Limited research in the Asian context surrounded by ambiguity of findings calls for greater investigation into this area. Hence, this research also embarks on filling contextual gap in this research area. Further, as regards Malaysia, it could be considered as amongst one of the most suitable countries for this research as there has been abundance of multi-business companies over here for last many years (Ahmad, Ishak, \& Manaf, 2003; Ishak \& Napier, 2006).

Coupled with that, Malaysia is also confronted with international and national level challenges to pursue its national programmes and continue with the growth agenda. Although Malaysian GDP growth rate is expected to surpass 5.5\% during 2014, but recent years are expected to bring challenges in form of rising unemployment, increasing cost of living, slowing down of real economic activity, and tightening credit conditions (Malaysian Institute of Economic Research [MIER], 2014). The economy is also facing international challenges in form of damping international demand and the present scenario signifies crucial role of Malaysian corporate sector for achieving growth targets and attaining economic balance.

The role of Malaysian manufacturing sector has been more significant since 1980's when Malaysia embarked transformation from commodity based manufacturing to manufacturing of high tech industrial products (Asid, 2010). This sector contributed about 25-32\% to Malaysia's GDP during last few years and is projected to persist as an important sector in the course of Third Malaysian Industrial Master Plan, 2006 to 2020 (Hassan, Muhammad, \& Ismail, 2011; Ministry of International Trade and Industry [MITI], 2013). Alternatively, Malaysian service sector, which contributes greater than 50\% to country's GDP, attained wonderful growth rate during past few years in several fields (MITI, 2013; Naqshbandi \& Idris, 2012). However, it is quite evident that in future, these sectors must carefully select their competitive priorities and manage their operations prudently for successfully dealing with international business scenarios (Hassan et al., 2011; Naqshbandi \& Idris, 2012). In the present circumstances, this research was considered imperative as it was designed to guide Malaysian directors and corporate policy makers regarding the course of diversification strategy.

\section{Literature Review}

\subsection{Product diversification and types}

Product diversification is a growth strategy where a company expands into new markets or starts production of entirely new products or services (David, 2011; Haberberg \& Rieple, 2001). It could be pursued either in related industries or unrelated industries (Abdullah, 2009; Jones \& Hill, 2010).

\subsection{Related diversification strategy}

Related diversification is company's expansion into new products and markets but within the existing strategic capability (Grant, Butler, Hung, \& Orr, 2011; Johnson et al., 2008). In this strategy, company's new business activities are related with existing business activities (Harrison \& John, 2010; Lahovnik, 2011) and the businesses are similar to one another in terms of input and operational requirements (Teece, 1982; Thompson, Peteraf, Gamble, \& Strickland III, 2012). Companies like Cisco Systems, Honda, 3M, and Samsung are considered as related diversifiers (Harrison \& John, 2010; Jones \& Hill, 2010).

\subsubsection{Motives to follow related diversification strategy}

Scholars argument that the primary motive behind related diversification is creation of synergy (David, 2011; Grant et al., 2011). Relatedly diversified companies could gain both operative or growth synergy advantages and these could be 
obtainable through capability up gradation, scale effects, or entry into new market segments (Knoll, 2007; Morden, 2007). Additionally, synergy benefits could be available in form of economies of scope, market power, and internal governance (Martin \& Eisenhardt, 2001; Mehmood \& Hilman, 2013).

Related diversifiers might outperform unrelated ones on the basis of the economies of scope benefits available through sharing of capabilities and resources across businesses which might result in substantial cost or differentiation advantages (Galván, Pindado, \& la Torre, 2007; Haberberg \& Rieple, 2001; Hoskisson, Hitt, \& Ireland, 2009). Procter \& Gamble shares its marketing and R\&D costs across various businesses and hence enjoys economies of scope advantages over its competitors (Jones \& Hill, 2010).

Motives for related diversification are also active through increased market power (Hoskisson et al., 2009; Johnson et al., 2008). A diversified company could naturally outperform a focused one through tactics like predatory pricing or price cutting (Goddard, McKillop, \& Wilson, 2008; Klier, 2009), cross subsidization (Johnson et al., 2008; Lee, 2002), mutual forbearance (Bernheim \& Whinston, 1990; Martin \& Eisenhardt, 2001), and reciprocity (George, 2007; Palich et al., 2000). In particular, related diversifiers could gain benefits through backward and forward integration strategies (David, 2011; Gupta et al., 2007) as opposed to unrelated diversifiers.

Other synergy benefits in related diversifiers could be in form of internal governance advantages which are realized by having an efficient internal market which could facilitate rapid transfer of capital and other assets among various businesses (Martin \& Eisenhardt, 2001; Williamson, 1971). In fact, in related diversifiers, knowledge sharing, implementation of internal control systems and attaining collaboration or team work between different businesses could be easier in comparison to unrelated diversifiers and therefore in related ones, transaction costs and governance costs might be comparatively lower (Abdullah, 2009; Busija, O'Neill, \& Zeithaml, 1997). Hence, in reference to (TCE) transaction cost economies (Liu \& Hsu, 2011; Williamson, 1971), this provides definite cost and competitive advantages to related ones compared to their counterparts.

On the other side of it, these synergy programmes could be quite risky and might not meet management expectations (Goold \& Campbell, 1998; Haberberg \& Rieple, 2001) as they could increase interdependency among subsidiaries which might resist change process in certain subsidiaries (Hitt, Ireland, \& Hoskisson, 2011). Also, in related businesses, too much diversification might increase its marginal costs and erode all its benefits (Palich et al., 2000; Park, 2010).

\subsection{Unrelated diversification strategy}

Unrelated or conglomerate diversification is company's expansion beyond its current strategic capability (Johnson et al., 2008; Pearce II \& Robinson Jr., 2011) where its new businesses or subsidiaries have little or no relatedness with old businesses (Grant et al., 2011; Thompson et al., 2012). Companies like General Electric, Bidvest, Wesfarmers, Tata Group, Hitachi, and Royal Philips are some examples of conglomerates (Harrison \& John, 2010; Jones \& Hill, 2010; Kenny, 2012).

\subsubsection{Motives to follow unrelated diversification strategy}

The literature on conglomerates clearly depicts that reduction of overall company risk and increase in profitability have been main motives behind this strategy (Grant et al., 2011; Michel \& Shaked, 1984). In contrast to focused companies or related ones, unrelated diversifiers have better position to create financial synergies by transferring capital across different businesses and through operating various businesses with different risk profiles (Berger \& Ofek, 1995; Galván et al., 2007). In a huge conglomerate, these benefits are easily attainable through large internal capital market capable of generating substantial financial economies (Hoskisson et al., 2009).

However, the benefits of internal capital markets are reap able particularly in developing economies. It is because, external markets are not properly developed in those economies, and thus internal capital market proves more rewarding (Fan, Huang, Oberholzer-Gee, Smith, \& Zhao, 2008). Similarly, external environmental conditions also have an important role to play. For instance, in their study of US firms, Kuppuswamy and Villalonga (2010) concluded that value of unrelated diversification increased during 2008-09 crises because of the 'smarter-money' and 'more-money' effect associated with internal capital markets.

Another motive associated with unrelated diversification is attainment of financial economies through business restructuring (Bamford \& West, 2010). Under this, a company would acquire unrelated business which is undervalued and use its financial expertise and capable governance to convert the business into profitable subsidiary for sale at higher price later on (Bamford \& West, 2010; Johnson et al., 2008). 


\subsection{Conclusion}

The previous discussion implies that there could be several reasons and motivations for pursuing diversification strategies. The motives for pursuing these strategies are best explained through theories of TCE and internal market efficiency (Bhide, 1993; Williamson, 1971), market power theory (George, 2007; Martin \& Eisenhardt, 2001), resource based view - RBV (Teece, 1982; Wernerfelt, 1984), and the agency theory (Aggarwal \& Samwick, 2003; Amihud \& Lev, 1981). We strongly encourage readers to consult the cited references for greater understanding of the diversification motives.

\subsection{Related diversification strategy versus unrelated diversification strategy}

\subsubsection{Introduction and background}

The review of relevant literature concludes that much like the ambiguity about product diversification - performance relationship (Marinelli, 2011; Nippa, Pidun, \& Rubner, 2011), the mystery concerning superiority of related or unrelated diversification strategy is also unsolved (Lahovnik, 2011; Mehmood \& Hilman, 2013; Palich et al., 2000). Rumelt, in 1974, pioneered the research of comparing related diversifiers against unrelated diversifiers and reported that former ones performed better than later ones. His findings were later on supported by Christensen and Montgomery (1981) and validated by himself in 1982. Subsequently, Michel and Shaked (1984) revealed conflicting results by reporting that unrelated diversifiers performed better than related ones on market measures of performance. Afterwards, several attempts were made to compare the two strategies on various performance measures.

\subsubsection{Studies supporting superiority of related diversification strategy against unrelated diversification strategy}

Several scholars concluded in favour of related diversification outperforming unrelated diversification (Galván et al., 2007; Markides \& Williamson, 1996; Mishra \& Akbar, 2007; Rumelt, 1974, 1982). Firstly, thorough analysis of their studies reveals that they were different from one another about how they measured diversification strategies and also produced different conclusions. For example, some studies used Rumelt's (1974) categorical schemes for measuring diversification (Christensen \& Montgomery, 1981; Rumelt, 1982), others employed simple categorical measures (Berger \& Ofek, 1995; Mishra \& Akbar, 2007), while certain others utilized entropy measure (Palepu, 1985).

Also, the studies comparing related versus unrelated diversifiers employed different measures of performance. For instance, some studies used accounting indicators (Markides \& Williamson, 1996; Rumelt, 1982), others employed market based performance ratios (Galván et al., 2007; Mishra \& Akbar, 2007) and certain other studies utilized a blend of market and accounting ratios (Berger \& Ofek, 1995; Varadarajan \& Ramanujam, 1987). Mixed results were reported by some studies that employed multiple indicators of performance (Christensen \& Montgomery, 1981; Varadarajan \& Ramanujam, 1987). Certain studies necessitated the need of including multiple performance measures in diversification studies for getting greater knowledge of the topic. Overall, use of different performance measures in these studies clearly points towards the robustness of findings and support that related diversifiers performed better than unrelated ones on various performance indicators.

There was also heterogeneity among those studies with respect to sample sizes, contexts and time frames. As regards sample size, Palepu's study (1985) was based on only 30 firms, while Berger and Ofek (1995) conducted study on a huge sample including 3659 firms. Similarly, Varadarajan and Ramanujam (1987) took sample from multiple sectors but Palepu's study (1985) relied on sample of firms belonging to food industry only. Also, there is substantial evidence of related diversification winning unrelated diversification in multiple contexts as those studies had diversified contexts such as Eurozone countries (Galván et al., 2007), Asia (Mishra \& Akbar, 2007) or Fortune companies (Rumelt, 1982). In summary, the general conclusion of all these studies supports superiority of related diversification against unrelated diversification.

\subsubsection{Studies supporting superiority of unrelated diversification strategy against related diversification strategy}

Substantial studies revealed that unrelated diversifiers performed better compared to related diversifiers (Dubofsky \& Varadarajan, 1987; Marinelli, 2011; Michel \& Shaked, 1984). As argued before, results of Michel and Shaked (1984) regarding superiority of unrelated diversification against their counterparts - were opposite to Rumelt's results (1974, 1982). Afterwards, their results were also confirmed by Dubofsky and Varadarajan (1987) who used same sample as of 
Michel and Shaked (1984). However, they differentiated their study through introduction of return on assets (ROA) as another performance dimension, but the findings, however, were not significant on ROA.

Lahovnik (2011) did his study in Slovenia and reported that on return on sales, unrelated diversification performed better than related diversification. In the same year 2011, Marinelli also reported results in favour of unrelated diversification. The studies reporting superiority of unrelated diversification against related diversification were also different from one another with respect to their research designs. However, their general conclusion supported superiority of unrelated diversification over related diversification.

Based on this critical review, it could be concluded that there is no definite consensus about relative superiority of one strategy over the other. Hence, following hypotheses are formulated:

$\mathrm{H1}$ : There is a significant difference between Related Diversifiers and Unrelated Diversifiers on return on assets.

$\mathrm{H} 2$ : There is a significant difference between Related Diversifiers and Unrelated Diversifiers on return on equity.

H3: There is a significant difference between Related Diversifiers and Unrelated Diversifiers on Tobin's q.

H4: There is a significant difference between Related Diversifiers and Unrelated Diversifiers on price/book value.

H5: There is a significant difference between Related Diversifiers and Unrelated Diversifiers on subjective corporate performance.

The justifications for the five dimensions of corporate performance appear in later sections of the article.

\subsection{Corporate performance}

In various fields, corporate performance has been widely used criterion for evaluating the impact of product diversification strategies (Hoechle, Schmid, Walter, \& Yermack, 2012; Kahloul \& Hallara, 2010). But, it went through variety of measurement techniques and acquired several indicators (Asrarhaghighi et al., 2013; Klier, 2009). However, in diversification research, majority of researchers used financial indicators of performance. Certain studies have been relying on accounting ratios (Busija et al., 1997; Delios \& Beamish, 1999; Marinelli, 2011), some studies employed market ratios of performance (Galván et al., 2007; Hoechle et al., 2012; Ishak \& Napier, 2006), and certain studies have been utilizing combination of accounting and market ratios (Daud et al., 2009; Kahloul \& Hallara, 2010; Ravichandran, Liu, Han, \& Hasan, 2009). While different performance measures in certain studies revealed different results (Michel \& Shaked, 1984; Rumelt, 1974), usage of similar performance measures in some researches also revealed different results (Hoechle et al., 2012; Miller, 2006; Mishra \& Akbar, 2007). This suggests use of different measures of corporate performance in a study for getting greater understanding of the topic.

Financial indicators of performance are often criticised for capturing after-the-fact consequences and other problems (Denton, 2005). For instance, though frequently used but accounting ratios could be associated with certain problems like non-standardization in their computations, assets' undervaluation and accounting manipulation (Asrarhaghighi et al., 2013; Chakravarthi, 1986). Likewise, although market based ratios reflect real market performance (Santos \& Brito, 2012) but they might too fail to reflect overall corporate performance from all respects. According to Venkatraman and Ramanujam (1986), financial performance represents just one part of organizational performance and it might not fully reflect strategy outcomes.

Certain other scholars argue that researchers must employ multiple performance measures which should focus on overall stakeholder issues and not only on shareholder issues (Asrarhaghighi et al., 2013; Micheli, Mura, \& Agliati, 2011). Therefore, certain past studies also relied on obtaining subjective assessment of corporate performance in their research (Nandakumar, Ghobadian, \& O'Regan, 2010; Tan, Chang, \& Lee, 2007). Wall et al. (2004) established validity of subjective performance measures against objective ones and suggested using together objective as well as subjective measures of performance. While embarking on these ideas, this study relied on combination of objective (accounting and market based financial ratios) and subjective measures of corporate performance.

\section{Research Methodology}

\subsection{Population}

The population frame consisted of all diversified public limited companies listed on Bursa Malaysia. Diversified companies were identified on the basis of number of business segments reported in their annual reports. Reporting of business segments by all PLCs on Bursa Malaysia is mandatory for all companies as per FRS 8 Operating Segments ruling (Malaysian Accounting Standards Board [MASB], 2014; Malaysian Institute of Accountants [MIA], 2010). The unit of analysis in this research is public limited company. As there are substantial differences in the listing requirements of 
companies for the two markets of Bursa Malaysia (Main Market and ACE Market), therefore, PLCs listed on the Main Market of Bursa Malaysia were included in the study.

\subsection{Study's time frame}

This study was conducted by relying on three years data; 2010 to 2012. Reliance on three years data is consistent with studies of Singh, Davidson, and Suchard (2003), Afza et al. (2008), and Hill, Hitt, and Hoskisson (1992). This research is also in agreement with several past studies regarding calculation of financial ratios based on three years data (Afza et al., 2008; Christensen \& Montgomery, 1981; Singh et al., 2003). Selection of three years data was also inspired by the conversion of business segments reporting standard from FRS $114_{2004}$ to FRS 8 which was eventually adopted by PLCs since 2010 (MASB, 2014; MIA, 2010).

\subsection{Measurement of product diversification strategy and classification of PLCs into groups}

This research utilized Jacquemin and Berry's Entropy measure (1979) to calculate product diversification scores for every PLC. This selection was based on the characteristic that the technique provides overall diversification score with the ability to split the total score into related and unrelated diversification scores (Chari, Devaraj, \& David, 2008; Palepu, 1985). However, for computation, Entropy measure requires Standard Industrial Classification (SIC) Codes which are not readily available for Malaysian PLCs. Therefore, to assign SIC codes to companies' business segments, help was taken from Thomson Reuters Worldscope Database. Specifically, following formulae were used:

Total Product Diversification Score (DT) was computed as:

$\mathrm{DT}=\sum_{i=1}^{N} P_{i} \ln \left(1 / P_{i}\right)$

$\mathrm{Pi}=$ share of ith business segment in total company sales

$\mathrm{N}=$ Total number of industry segments a company is operating

Related Diversification Score (DR) was computed as:

$\mathrm{DR}=\sum_{j=1}^{M} \mathrm{DR}_{j} P^{P}$

$\mathrm{Pj}=$ share of $j$ th group sales in total company sales

$M=$ Number of industry groups a company is operating

In the above formula, DRj could be computed as:

$\mathrm{DR}_{i}=\sum_{\pi, j} P_{i} \ln \left(1 / P_{i}\right)$

$\mathrm{PJ}_{i}=$ share of the segment $i$ of group $j$ in the total sales of the group

Unrelated Diversification Score (DU) was computed as:

$\mathrm{DU}=\sum_{=1}^{M} P_{j} \ln \left(1 / P^{j}\right)$

$\mathrm{Pj}=$ share of $j$ th group sales in the total company sales

$M=$ Number of industry groups a company is operating

The three entropy scores were calculated manually for all PLCs by taking required information from annual reports, and on this basis, each PLC was classified as dominantly related diversifier or dominantly unrelated diversifier.

\subsection{Measurement of corporate performance}

\subsubsection{Measurement of objective corporate performance}

This study utilized return on assets ROA (Lahovnik, 2011; Ravichandran et al., 2009), return on equity ROE (Delios \& Beamish, 1999; Goddard et al., 2008), Tobin's q, and price to book value (P/B Value) as four indicators of performance. ROA provides measurement regarding total profit produced by every dollar invested in assets (Ross, Westerfield, Jaffe, \& Jordan, 2011). ROA was measured through dividing Net Income by Total Assets (Afza et al., 2008; Pandya \& Rao, 1998). ROE provides measurement about how much profit is being created by per dollar invested in equity (Ross et al., 2011). ROE was measured through dividing Net Income by Total Equity (Afza et al., 2008; Pandya \& Rao, 1998).

Among market measures of performance, Tobin's q has been quite popular (Kahloul \& Hallara, 2010; Ravichandran et al., 2009). It provides good measurement of profitability as there are less chances of accounting distortions in it, it is based on stock market values which not only provides current profitability but also reflects future profitability as judged by stock market reactions (David, O'Brien, Yoshikawa, \& Delios, 2010; Ravichandran et al., 2009). Following formula was used to calculate Tobin's q (Fukui \& Ushijima, 2006; Kahloul \& Hallara, 2010): 
Tobin's $q=\quad$ (Market Value of Equity + Book Value of Liabilities)

(Book Value of Equity + Book Value of Liabilities)

Regarding price to book value, limited studies utilized this ratio for measuring company performance which is reflective of a research gap (Elsas, Hackethal, \& Holzhäuser, 2010; Hill \& Hansen, 1991). Price to book value provides better measurement of company performance as it is also based on real stock market data, gives indication about value addition made by management and provides strategists feedback about market's evaluation of their managerial decisions (Berk, DeMarzo, \& Harford, 2009). Price to book value was computed by dividing market price per share by book value per share. Information about various accounts for calculating ratios was taken from company annual reports. Information regarding share price for computing price to book value and Tobin's q was obtained from Yahoo! Finance (Giblin, 2013; Harper, 2011).

\subsubsection{Measurement of subjective corporate performance (SCP)}

SCP was measured through adapting questionnaire comprising of ten items developed by Tan et al. (2007) based on past studies comprising those of Venkatraman and Ramanujam (1986) and Singh, Mathur, Gleason, and Etebari (2001) about firm performance. The items were based on following performance dimensions: return on assets, return on equity, sales growth rate, market share, acquisition of resources, productivity and efficiency, capacity utilization rate, availability of information, period for new product introduction, cohesive workforce. These dimensions were measured using 7-point Multiple Rating List Scale and secured respondents' assessment of company performance on these dimensions for three years.

For evaluating questionnaire's validity, exploratory factor analysis was done. EFA was performed by extracting factors with eigenvalues more than 1.0, using principal components analysis, selecting varimax as rotation method, and suppressing absolute values lower to 0.3 . The final solution resulted into 9 items loading onto one component with KMO value of 0.899 and significant $(p=0.000)$ Bartlett's Test of Sphericity. The component had Eigenvalue of 5.423 and explained about $60 \%$ of cumulative variance. Cronbach's alpha for reliability was also found satisfactory $(0.915)$.

\subsection{Sample size}

Of around 800 PLCs listed on Main Market of Bursa Malaysia during 2010 - 2012, there were 590 diversified PLCs (reported multiple business segments). However, 27 PLCs were screened out due to non-availability of sales data for one or more of their product segments. Hence, mail questionnaires were sent to all remaining 563 PLCs' top managers out of which 136 PLCs (24.15\%) replied the questionnaires. 13 PLCs were deleted from the analysis due to incomplete questionnaires and final analysis was performed for 123 PLCs.

\section{Findings}

Based on study's time period (2010 to 2012), a three year average entropy score was calculated and an average of three years was taken for all the performance dimensions for each company. Firstly, Table 1 presents sector wise classification of participating companies It shows that highest number of PLCs (33) participated from Trading/Services sector followed by those from Industrial Product's sector (30), whereas, only one company participated from REIT sector.

Table 1. Sector Wise Classification of Participating Companies

\begin{tabular}{|c|l|c|}
\hline No. & Sector & Number of PLCs \\
\hline 1 & Industrial Product & 30 \\
\hline 2 & Finance & 8 \\
\hline 3 & Trading/Services & 33 \\
\hline 4 & Consumer & 8 \\
\hline 5 & Properties & 22 \\
\hline 6 & Plantation & 7 \\
\hline 7 & Construction & 9 \\
\hline 8 & Real Estate Investment Trust (REIT) & 1 \\
\hline 9 & Technology & 5 \\
\hline & Total & 123 \\
\hline
\end{tabular}


Table 2 presents descriptive statistics. It indicates that DR (related diversification entropy score) was as high as 1.689, whereas DU (unrelated diversification entropy score) was comparatively lower with 1.284 as maximum. Overall mean of ROE (0.0564) was greater than that of ROA (0.0162), while there didn't seem to be much difference between the means of Tobin's q and price/book value. SCP was ranging as low as 2.56 to as high as 7.00 with mean of 4.74 .

Table 2. Descriptive Statistics

\begin{tabular}{|c|c|c|c|c|c|c|}
\hline & Min. & Max. & Range & Mean & Variance & Std. Deviation \\
\hline DT & .017463 & 1.689052 & 1.671589 & .63950524 & .132 & .363805848 \\
\hline DR & .000000 & 1.689052 & 1.689052 & .28802400 & .112 & .334689883 \\
\hline DU & .000000 & 1.284302 & 1.284302 & .35148100 & .123 & .350981631 \\
\hline ROA & -1.37 & .16 & 1.53 & .0162 & .027 & .16532 \\
\hline ROE & -1.14 & .93 & 2.07 & .0564 & .045 & .21317 \\
\hline Tobinq & .30 & 2.62 & 2.32 & .9735 & .186 & .43167 \\
\hline Price/book value & .13 & 4.20 & 4.07 & .9633 & .533 & .72996 \\
\hline SCP & 2.56 & 7.00 & 4.44 & 4.7453 & .916 & .95684 \\
\hline
\end{tabular}

For analysis purposes, the companies were divided into two groups; Related Diversifiers and Unrelated Diversifiers on the basis of entropy scores. Every company was either dominantly related diversifier or dominantly unrelated diversifier. The two groups were compared against each other on all performance dimensions, using independent samples t-tests. Results of the analyses are presented in Table 3 and Table 4.

Table 3 presents group statistics for all performance dimensions. It shows that means of ROA, Tobin's q, and P/B Value for DR (Related Diversifiers) were higher than those for DU (Unrelated Diversifiers). Interestingly, means of both groups for ROE were same (0.0564). Mean of SCP for DU was greater than that of DR. Now let us take a look on Table 4 that presents the results of the t-tests. As all the hypotheses were non-directional, therefore they required conducting 2tailed t-tests.

Table 3. Group Statistics of Unrelated Diversifiers and Related Diversifiers for all Dimensions of Corporate Performance

\begin{tabular}{|c|c|c|c|c|c|}
\hline Performance & Group & $\mathrm{N}$ & Mean & Std. Deviation & Std. Error Mean \\
\hline \multirow{2}{*}{ ROA } & DR & 56 & 0.0380 & 0.06160 & 0.00823 \\
\cline { 2 - 6 } & DU & 67 & -0.0021 & 0.21591 & 0.02638 \\
\hline \multirow{2}{*}{ ROE } & DR & 56 & 0.0564 & 0.16678 & 0.02229 \\
\cline { 2 - 6 } & DU & 67 & 0.0564 & 0.24662 & 0.03013 \\
\hline \multirow{2}{*}{ Tobin's q } & DR & 56 & 1.0559 & 0.42450 & 0.05673 \\
\cline { 2 - 6 } & DU & 67 & 0.9046 & 0.42861 & 0.05236 \\
\hline \multirow{2}{*}{ P/B Value } & DR & 56 & 1.1354 & 0.78826 & 0.10534 \\
\cline { 2 - 6 } & DU & 67 & 0.8194 & 0.64885 & 0.07927 \\
\hline \multirow{2}{*}{ SCP } & DR & 56 & 4.7282 & 0.99875 & 0.13346 \\
\cline { 2 - 6 } & DU & 67 & 4.7595 & 0.92773 & 0.11334 \\
\hline
\end{tabular}

Table 4 depicts that there were no significant differences between DR and DU on ROA, ROE and SCP. However, significant differences between the two groups were revealed on both market measures of performance i.e. Tobin's q (Sig. $=0.053)$ and P/B value (Sig. = 0.016). By having a collective look on Table 3 and Table 4, it can be said that as Table 3 indicates higher means of Tobin's $q$ and Price/Book Value for DR against DUs and Table 4 indicates significant performance differences between the two groups on the two measures, therefore, it could be established that DRs performed better than DUs on both market measures of performance.

With 1-tailed hypotheses (proposing superiority of related diversifiers against unrelated ones), it would clearly conclude that related diversifiers performed better than unrelated ones not only on Tobin's q (Sig. $=0.0265,0.053 / 2)$ and price/book value (Sig. $=0.008,0.016 / 2$ ), but on ROA as well (Sig. $=0.075,0.150 / 2$ ). However, with the original hypotheses developed in section 2.5.3, the findings resulted in acceptance of Hypothesis 3 and 4 and the results are discussed in length in section 5. 
Table 4. T-tests' Results for Comparing Unrelated Diversifiers against Related Diversifiers on all Dimensions of Corporate Performance

\begin{tabular}{|c|c|c|c|c|c|c|c|c|c|}
\hline & \multicolumn{3}{|c|}{$\begin{array}{c}\text { Levene's Test for Equality } \\
\text { of Variances }\end{array}$} & \multicolumn{6}{|c|}{ t-test for Equality of Means } \\
\hline & & \multirow[t]{2}{*}{$F$} & \multirow[t]{2}{*}{ Sig. } & \multirow[t]{2}{*}{ df } & \multirow[t]{2}{*}{$\begin{array}{l}\text { Sig. (2- } \\
\text { tailed) }\end{array}$} & \multirow[t]{2}{*}{$\begin{array}{c}\text { Mean } \\
\text { Difference }\end{array}$} & \multirow[t]{2}{*}{$\begin{array}{c}\text { Std. Error } \\
\text { Difference }\end{array}$} & \multicolumn{2}{|c|}{$\begin{array}{l}\text { 95\% Confidence Interval of } \\
\text { the Difference }\end{array}$} \\
\hline & & & & & & & & Lower & Upper \\
\hline \multirow{2}{*}{ ROA } & 1 & 2.861 & .093 & $1.345 \quad 121$ & .181 & .04013 & .02983 & -.01894 & .09919 \\
\hline & 2 & & & 1.45278 .586 & .150 & .04013 & .02763 & -.01488 & .09513 \\
\hline \multirow{2}{*}{ ROE } & 1 & .490 & .485 & $.000 \quad 121$ & 1.000 & .00001 & .03876 & -.07672 & .07674 \\
\hline & 2 & & & .000116 .229 & 1.000 & .00001 & .03748 & -.07421 & .07424 \\
\hline \multirow{2}{*}{$\begin{array}{c}\text { Tobin's } \\
q\end{array}$} & 1 & .087 & .768 & $\begin{array}{ll}1.958 & 121\end{array}$ & .053 & .15127 & .07727 & -.00170 & .30424 \\
\hline & 2 & & & 1.959117 .543 & .052 & .15127 & .07720 & -.00162 & .30415 \\
\hline \multirow{2}{*}{$\begin{array}{c}\text { P/B } \\
\text { Value }\end{array}$} & 1 & 1.787 & .184 & $2.439 \quad 121$ & .016 & .31595 & .12957 & .05944 & .57246 \\
\hline & 2 & & & 2.397106 .477 & .018 & .31595 & .13183 & .05460 & .57731 \\
\hline \multirow{2}{*}{ SCP } & 1 & .505 & .479 & $\begin{array}{ll}.180 & 121\end{array}$ & .857 & -.03136 & .17394 & -.37571 & .31299 \\
\hline & 2 & & & -.179113 .669 & .858 & -.03136 & .17510 & -.37823 & .31551 \\
\hline
\end{tabular}

1 (Equal variances assumed)

2 (Equal variances not assumed)

\section{Discussion}

There is substantial support from the literature about related diversification strategy outperforming unrelated diversification strategy on different performance dimensions (Christensen \& Montgomery, 1981; Galván et al., 2007; Rumelt, 1974, 1982). Specifically, the results are in line with studies revealing related diversifiers did better than unrelated diversifiers on market indicators of performance (Berger \& Ofek, 1995; Galván et al., 2007; Mishra \& Akbar, 2007; Varadarajan \& Ramanujam, 1987). Particularly, the findings agree with those of Mishra and Akbar (2007) who conducted study on Indian companies and suggested that related diversifiers performed better than unrelated diversifiers on Tobin's q.

As discussed before, market performance ratios could better judge performance compared to accounting ratios (Chakravarthi, 1986; Santos \& Brito, 2012). As debated earlier, Tobin's q has been very popular and widely used market ratio of performance (Kahloul \& Hallara, 2010; Ravichandran et al., 2009) and a number of previous studies used it in their research frameworks for gauging performance (Chari et al., 2008; Fukui \& Ushijima, 2006; Guo \& Cao, 2011). Therefore, the significant performance difference revealed on Tobin's $q$ highlight the importance of this research finding. Additionally, the findings regarding related diversifiers winning unrelated diversifiers on price/book value also becomes important as scholars point towards the validity of price/book value for reflecting corporate performance (Berk et al., 2009).

Moreover, the findings also have support from well-established management theories; market power theory, RBV, and TCE. As mentioned in literature review section, these theories have always forwarded the proposition that related diversification strategy could outperform unrelated diversification strategy (Palich et al., 2000; Rumelt, 1974). As regards TCE, the scholars suggested that conglomerates could be less successful compared to related diversifiers because in later ones implementing control systems, sharing of knowledge, and gaining cooperation among various businesses could be more easier in contrast to that in former ones (Abdullah, 2009; Busija et al., 1997). Hence, as argued before, related diversifiers could gain more due to greater opportunities to create and share synergy benefits among businesses due to greater relatedness among them (Knoll, 2007; Morden, 2007). Related diversifiers could gain competitive advantage over unrelated ones through forward and backward integration which result in substantial benefits available in form of savings in production and transaction costs (David, 2011; Gupta et al., 2007).

Also, the results support resource based theory arguments that related diversification could provide greater synergistic advantages in form of internal governance benefits through transferring common inputs and resources, by providing common brand image, and through economies of scope benefits (Martin \& Eisenhardt, 2001; Palich et al., 2000). These sorts of opportunities might not be with unrelated diversifiers (Ravichandran et al., 2009). In a way, the findings also lend support to market power theory which indicates that related diversifiers could be at better position compared to unrelated ones due to greater intra organization integration, and having better position to play multipoint competition for putting more pressures on their competitors (Hitt et al., 2011; Johnson et al., 2008). 
The findings overall, support similar results produced by numerous past studies, though conducted in different contexts. Yet, it is established by this study that even in developing countries like Malaysia, related diversification could provide greater benefits to companies as compared to unrelated diversification. Hence, the findings recommend strategists, particularly Malaysian strategists working in various sectors to look for diversification opportunities in related industries and sectors instead of unrelated ones for improving their market performance.

\section{Limitations and Future Research}

The findings are mainly applicable to sectors covered and to Malaysian PLCs or PLCs working in similar macro environments. To further enrich the topic, future research must look into making cross comparisons between PLCs working in similar to different business environments. Future studies could also attempt measuring diversification strategies and performance using more powerful methods and try using more than one approach to measure related and unrelated diversification strategies to reveal interesting results. Use of longitudinal studies and time series data for comparing the two strategies could also prove useful.

\section{References}

Abdullah, H. H. (2009). The relationship of competitive strategy, strategic flexibility and sourcing strategy on organizational performance. (Unpublished Doctoral dissertation). Universiti Putra Malaysia.

Afza, T., Slahudin, C., \& Nazir, M. S. (2008). Diversification and corporate performance: An evaluation of Pakistani firms. South Asian Journal of Management, 15(3), 7-18.

Aggarwal, R. K., \& Samwick, A. A. (2003). Why do managers diversify their firms? Agency reconsidered. The Journal of Finance, 58(1), 71-118.

Ahmad, A. C., Ishak, Z., \& Manaf, N. A. (2003). Corporate governance, ownership structure and corporate diversification: Evidence from the Malaysian listed companies. Asian Academy of Management Journal, 8(2), 67-89.

Amihud, Y., \& Lev, B. (1981). Risk reduction as a managerial motive for conglomerate mergers. Bell Journal of Economics, 12(2), 605-617.

Asid, R. (2010). The technical efficiency analyses of manufacturing sector in Malaysia: Evidence from the First Industrial Master Plan (19861995). Asian Social Science, 6(2), 99-107.

Asrarhaghighi, E., Rahman, A. A., Sambasivan, M., \& Mohamed, Z. A. (2013). Diversification strategy and performance studies: Results, measures, and sampling design. Journal of Advanced Management Science, 1(1), 12-18. doi: 10.12720/joams.1.1.12-18

Bamford, C. E., \& West III, G. P. (2010). Strategic management: Value creation, sustainability and performance. USA: South-Western, Cengage Learning.

Benito-Osorio, D., Guerras-Martin, L. A., \& Zuniga-Vicente, J. A. (2012). Four decades of research on product diversification: A literature review. Management Decision, 50(2), 325-344. doi: 10.1108/00251741211203597

Berger, P., \& Ofek, E. (1995). Diversification's effect on firm value. Journal of Financial Economics, 37(1), 39-65.

Berk, J., DeMarzo, P., \& Harford, J. (2009). Fundamentals of corporate finance. USA: Pearson Education, Inc.

Bernheim, B. D., \& Whinston, M. D. (1990). Multimarket contact and collusive behavior. RAND Journal of Economics, 21(1), 1-26.

Bhide, A. (1993). Reversing corporate diversification. In D. H. Chew, Jr. (Ed.), The new corporate finance: Where theory meets practice (pp. 526537). NY: McGraw-Hill.

Busija, E. C., O'Neill, H. M., \& Zeithaml, C. P. (1997). Diversification strategy, entry mode, and performance: Evidence of choice and constraints. Strategic Management Journal, 18(4), 321-327.

Chakrabarti, A., Singh, K., \& Mahmood, I. (2007). Diversification and performance: Evidence from East Asian firms. Strategic Management Journal, 28, 101-120. doi: 10.1002/smj.572

Chakravarthy, B. S. (1986). Measuring strategic performance. Strategic Management Journal, 7(5), 437-458.

Chari, M. D. R., Devaraj, S., \& David, P. (2008). The impact of information technology investments and diversification strategies on firm performance. Management Science, 54(1), 224-234. doi 10.1287/mnsc.1070.0743

Christensen, H. K., \& Montgomery, C. A. (1981). Corporate economic performance: Diversification strategy versus market structure. Strategic Management Journal, 2(4), 327-343.

Daud, W. M. N. W., Salamudin, N. B., \& Ahmad, I. B. (2009). Corporate diversification and performance. International Business Education Journal, 2(1), 1-18.

David, F. R. (2011). Strategic management: Concepts. (13th edition). NJ: Pearson Education, Inc.

David, P., O'Brien, J. P., Yoshikawa, T., \& Delios, A. (2010). Do shareholders or stakeholders appropriate the rents from corporate diversification? The influence of ownership structure. Academy of Management Journal, 53(3), 636-654. doi: 10.5465/AMJ.2010.51469005

Delios, A., \& Beamish, P. W. (1999). Geographic scope, product diversification, and the corporate performance of Japanese firms. Strategic Management Journal, 20(8), 711-727.

Denton, D. K. (2005). Measuring relevant things. International Journal of Productivity and Performance Management, 54(4), 278-287. doi: $10.1108 / 17410400510593820$

Dubofsky, P., \& Varadarajan, P. R. (1987). Diversification and measures of performance: Additional empirical evidence. The Academy of Management Journal, 30(3), 597-608.

Elsas, R., Hackethal, A., \& Holzhäuser, M. (2010). The anatomy of bank diversification. Journal of Banking and Finance, 34, 1274-1287. doi:10.1016/j.jbankfin.2009.11.024

Fan, J. P. H., Huang, J., Oberholzer-Gee, F., Smith, T. D., \& Zhao, M. (2008). Diversification of Chinese companies: An international comparison. 
Chinese Management Studies, 2(1), 6-13. doi: 10.1108/17506140810866223

Fukui, Y., \& Ushijima, T. (2006). Corporate diversification, performance, and restructuring in the largest Japanese manufacturers. Journal of the Japanese \& International Economies, 21(3), 303-323. doi: 10.1016/j.jjie.2006.06.002

Galván, A., Pindado, J., \& De la Torre, C. (2007). Diversification: value-creating or value-destroying strategy? Evidence from using panel data. Retrieved from http://gredos.usal.es/jspui/bitstream/10366/17425/1/DAEE_04_07_Diversification.pdf

George R. P. (2007). Diversification and firm performance: The moderating influence of ownership structure and business group-affiliation. South Asian Journal of Management, 14(3), 66-94.

Giblin, G. R. (2013). The effects of shareholder proposals on stock price: A study of S\&P 500 Companies. (Unpublished DBA dissertation). Golden Gate University, California, United states.

Goddard, J., McKillop, D., \& Wilson, J. O. S. (2008). The diversification and financial performance of US credit unions. Journal of Banking and Finance, 32, 1836-1849. doi:10.1016/j.jbankfin.2007.12.015

Goold, M., \& Campbell, A. (1998). Desperately seeking synergy. Harvard Business Review, September-October, 131-143.

Grant, R., Butler, B., Hung, H., \& Orr, S. (2011). Contemporary strategic management: An Australasian perspective. Australia: John Wiley \& Sons.

Guo, Z. F., Cao, L. (2011, May). Revisiting the effect of diversification on firm performance. Global Conference on Business and Finance Proceedings, 6(2), San Jose, Costa Rica.

Gupta, V., Gollakota, K., \& Srinivasan, R. (2007). Business policy and strategy management: Concepts and applications (2nd edition). India: Prentice-Hall.

Haberberg, A., \& Rieple A. (2001). The strategic management of organisations. England: Pearson Education Limited.

Harper, A. H. (2011). Comovements and stock market integration between India and its top trading partners: A multivariate analysis of international portfolio diversification. (Unpublished Doctoral dissertation). Capella University, Minneapolis, United States.

Harrison, J. S., \& John, C. H. S. (2010). Foundations in strategic management (5th edition). USA: South-Western, Cengage Learning.

Hassan, N. H. N., Muhammad, N. M. N., \& Ismail, Z. (2011). Strategic management accounting practice in Malaysia: Case of manufacturing sector. Journal of Finance, Accounting and Management, 2(2), 23-38.

Hill, C. W. L., \& Hansen, G. S. (1991). A longitudinal study of the cause and consequences of changes in diversification in the U.S. pharmaceutical industry 1977-1986, Strategic Management Journal, 12, 187-199.

Hill, C. W. L., Hitt, M. A., \& Hoskisson, R. E. (1992). Cooperative versus competitive structures in related and unrelated diversified firms. Organization Science, 3(4), 501-521.

Hitt, M. A., Ireland, R. D., \& Hoskisson, R. E. (2011). Strategic management: Competitiveness and globalization (9th edition). USA: SouthWestern, Cengage Learning.

Hoechle, D., Schmid, M., Walter, I., \& Yermack, D. (2012). How much of the diversification discount can be explained by poor corporate governance? Journal of Financial Economics, 103, 41-60. doi:10.1016/j.jineco.2011.03.025

Hoskisson, R. E., Hitt, M. A., \& Ireland, R. D. (2009). Business strategy: Theory and cases (2nd edition). USA: South-Western, Cengage Learning.

Ishak, Z., \& Napier, C. (2006). Expropriation of minority interests and corporate diversification in Malaysia. Asian Academy of Management Journal of Accounting and Finance, 2, 85-113.

Jacquemin, A. P., \& Berry, C. H. (1979). Entropy measure of diversification and corporate growth. The Journal of Industrial Economics, 27(4), 359-369.

Johnson, G., Scholes, K., \& Whittington, R. (2008). Exploring corporate strategy: Text and cases (8th edition). NJ: Prentice Hall.

Jones, G. R., \& Hill, C. W. L. (2010). Theory of strategic management: With cases (9th edition). USA: South-Western, Cengage Learning.

Jusoh, R., \& Parnell, J. A. (2008). Competitive strategy and performance measurement in the Malaysian context. An exploratory study. Management Decision, 46(1), 5-31. doi: 10.1108/00251740810846716

Kahloul, I., \& Hallara, S. (2010). The impact of diversification on firm performance and risk: An empirical evidence. International Research Journal of Finance and Economics, 35, 150-162.

Kenny, G. (2012). Diversification: Best practices of the leading companies. Journal of Business Strategy, 33(1), 12-20. doi: $10.1108 / 02756661211193776$

Klier, D. O. (2009). Managing diversified portfolios: What multi-business firms can learn from private equity. Germany: Physica-Verlag Heidelberg.

Knoll, S. (2007). Cross-Business synergies: A typology of cross-business synergies and a mid-range theory of continuous growth synergy realization. (Unpublished Doctoral dissertation). University of St. Gallen, Switzerland.

Kuppuswamy, V., \& Villalonga, B. (2010). Does diversification create value in the presence of external financing constraints? Evidence from the 2008-2009 financial crisis (No. 1569546). Harvard Business School Finance Working Paper. Retrieved from http://www.bus.umich.edu/Academics/Departments/Finance/Sem\%20Papers/F2010\%20Villalonga.pdf

Lahovnik, M. (2011). Corporate strategies in the post-transition economy: The case of Slovenian companies. The Journal of Applied Business Research, 27(1), 61-68.

Lee, S. C. (2002). Corporate diversification and performance: Evidence from Korea. (Doctoral Dissertation). Retrieved from Proquest Dissertations and Theses. (UMI 3070635).

Lins, K. V., \& Servaes, H. (2002). Is corporate diversification beneficial in emerging markets? Financial Management, Summer, 5-31.

Liu, H-Y., \& Hsu, C-W. (2011). Antecedents and consequences of corporate diversification: A dynamic capabilities perspective. Management Decision, 49(9), 1510-1534. doi: 10.1108/00251741111173961

Malaysian Accounting Standards Board (2014). Financial Reporting Standard 8: Operating Segments. Retrieved from http://www.masb. org.my/index.php?option=com_content\&view=article\&id=1272

Malaysian Institute of Accountants. (2010). FRS 8 operating segments, Accountants Today, January, 40-51. Retrieved from www.mia.org.my/at/at/2010/01/06.pdf

Malaysian Institute of Economic Research (2014). Malaysian economic outlook (4th quarter 2013 update). Retrieved from http://www.mier.org.my/outlook/archives/2014_01.html 
Marinelli, F. (2011, February). The relationship between diversification and firm's performance: Is there really a causal relationship? (No. 907). IESE Business School, University of Navarra Working Paper. Retrieved from http://www.iese.edu/research/pdfs/DI-0907-E.pdf

Markides, C. C., \& Williamson, P. J. (1996). Corporate diversification and organizational structure: A resource-based view. The Academy of Management Journal, 39(2), 340-367.

Martin, J. A., \& Eisenhardt, K. M. (2001). Exploring cross-business synergies. Academy of Management Proceedings, Washington, D.C.

Mehmood, K. K., \& Hilman, H. (2013, June). Four decades of academic research on product diversification - performance relationship: Analysis and foresight. Presented in the 10th Annual World Congress of the Academy for Global Business Advancement, Bangkok, Thailand.

Michel, A., \& Shaked, I. (1984). Does business diversification affect performance? Financial Management, 13(4), 18-25.

Micheli, P., Mura, M., \& Agliati, M. (2011). Exploring the roles of performance measurement systems in strategy implementation: The case of a highly diversified group of firms. International Journal of Operations \& Production Management, 31(10), 1115-1139. doi: 10.1108/01443571111172453

Miller, D. J. (2006). Technological diversity, related diversification, and firm performance. Strategic Management Journal, 27, 601-619. doi: $10.1002 / \mathrm{smj} .533$

Ministry of International Trade and Industry (2013). MITI weekly bulletin, 228. MY: MITI

Mishra, A., \& Akbar, M. (2007). Empirical examination of diversification strategies in business groups. Evidence from emerging markets. International Journal of Emerging Markets, 2(1), 22-38. doi: 10.1108/17468800710718877

Morden, T. (2007). Principles of strategic management (3rd edition). USA: Ashgate Publishing Company.

Nandakumar, M. K., Ghobadian, A., \& O'Regan, N. (2010). Business-level strategy and performance: The moderating effects of environment and structure. Management Decision, 48(6), 907-939. doi: 10.1108/00251741011053460

Naqshbandi, M. M, \& Idris, F. (2012). Competitive priorities in Malaysian service industry. Business Strategy Series, 13(6).

Nippa, M., Pidun, U., \& Rubner, H. (2011). Corporate portfolio management: Appraising four decades of academic research. Academy of Management Perspectives, 25(4), 50-66.

Palepu, K. (1985). Diversification strategy, profit performance and the entropy measure. Strategic Management Journal, 6(3), 239-255.

Palich, L. E., Cardinal, L. B., \& Miller, C. C. (2000). Curvilinearity in the diversification performance linkage: An examination of over three decades of research. Strategic Management Journal, 21(2), 155-174.

Pandya, A. M., \& Rao, N. V. (1998). Diversification and firm performance: An empirical evaluation. Journal of Financial and Strategic Decisions, $11(2), 67-81$.

Park, K. M. (2010). Diversification strategy and firm performance: A study of the restaurant industry. (Doctoral Dissertation). Retrieved from Proquest Dissertations and Theses. (UMI 3444833).

Pearce II, J. A., \& Robinson Jr., R. B. (2011). Strategic management: Formulation, implementation and control (12th edition). NY: McGrawHill//rwin.

Ravichandran, T., Liu, Y., Han, S., \& Hasan, I. (2009). Diversification and firm performance: Exploring the moderating effects of information technology spending. Journal of Management Information Systems, 25(4), 205-240. doi: 10.2753/MIS0742-1222250407

Ross, S. A., Westerfield, R. W., Jaffe, J. F., \& Jordan, B. D. (2011). Corporate finance: Core principles \& applications (3rd edition). NY: McGrawHill//rwin.

Rumelt, R. P. (1974). Strategy, structure, and economic performance. Boston: Harvard University Press.

Rumelt, R. P. (1982). Diversification strategy and profitability. Strategic Management Journal, 3(4), 359-369.

Santos, J. B., \& Brito, L. A. L. (2012). Toward a subjective measurement model for firm performance. Brazilian Administration Review, 9(Special Issue), 95-117.

Singh, M., Davidson, W. N., \& Suchard, J-A. (2003). Corporate diversification strategies and capital structure. The Quarterly Review of Economics and Finance, 43, 147-167.

Singh, M., Mathur, I., Gleason, K. C., \& Etebari, A. (2001). An empirical examination of the trend and performance implications of business diversification. Journal of Business \& Economic Studies, 7(2), 25-51.

Tan, B., Chang, H-C., \& Lee, C-K. (2007). Relationships among industry environment, diversification motivations and corporate performance: An empirical study of the automobile industry in Taiwan. International Journal of Commerce and Management, 17(4), 326-346. doi: $10.1108 / 10569210710844390$

Teece, D. J. (1982). Towards an economic theory of the multiproduct firm. Journal of Economic Behaviour and Organization, 3, 39-63.

Thompson, A. A., Peteraf, M. A., Gamble, J. E., \& Strickland III, A. J. (2012). Crafting and executing strategy. (18th edition). NY: McGrawHill//rwin.

Thomson Reuters (2012). Worldscope Database - Data definitions guide (issue 14). NY: Thomson Reuters.

Varadarajan, P. R., \& Ramanujam, V. (1987). Diversification and performance: A re-examination using a new two-dimensional conceptualization of diversity in firms. The Academy of Management Journal, 30(2), 380-393.

Venkatraman, N., \& Ramanujam, V. (1986). Measurement of business performance in strategy research: A comparison of approaches. The Academy of Management Review, 11(4), 801-814.

Wall, T. D., Michie, J., Patterson, M., Wood, S. J., Sheehan, M., Clegg, C. W. et al. (2004). On the validity of subjective measures of company performance. Personnel Psychology, 57, 95-118.

Wernerfelt, B. (1984). A resource-based view of the firm. Strategic Management Journal, 5, 171-180.

Williamson, O. E. (1971). The vertical integration of production: Market failure considerations. American Economic Review, 16, 112-123. 